\title{
International Capacity Cooperation and Financial Support of Countries along the "Chongqing-Xinjiang-Europe" under the background of the Belt and Road
}

\author{
Chuan Lin \\ Research Center for International Business and Economy, \\ Sichuan International Studies University, Chongqing 400031, China \\ Jingjing Luo \\ Research Center for International Business and Economy, \\ Sichuan International Studies University, Chongqing 400031, China
}

\begin{abstract}
International capacity cooperation is an effective way for Chinese enterprises to further expand the international market under the strategy of the Belt and Road Initiative. In this paper, based on the perspective of policy-oriented finance under the background of "The Belt and Road", and from the perspective of supporting finance, development finance, compensatory finance and welfare finance, the financial support problems in the process of national international production capacity along the "Chongqing-Xinjiang-Europe" are studied. This paper holds that to play the role of financial support, we should base on the national conditions, promote the construction and reform of policy-oriented financial institutions, adhere to the innovation and development of diversified financial support channels, pay attention to practice, establish a comprehensive risk management system, macro-co-ordination, improve the international production capacity cooperation planning.
\end{abstract}

Keywords: international Capacity Cooperation, Financial Support, Policy Finance, ChongqingXinjiang-Europe

\section{INTRODUCTION}

As an important form of implementation of the "Belt and Road Initiative," the concept of international capacity cooperation was originally derived from the meeting between Premier Li Keqiang and the president of Kazakhstan in late 2014. Since then, Premier Li Keqiang emphasized at the executive meeting of State Council on many occasions: "With international capacity cooperation, participating in global market competition and value reconstruction is a major opportunity to push forward the transformation and upgrading of the domestic industry, and promote China's economy towards the mid-to-high end." In May 2015, "the Guiding Opinions on Promoting International Capability and Equipment Manufacturing Cooperation" issued by the State Council, becoming an important road map for China to carry out international capacity cooperation. It also included international capacity cooperation into the new normal of China's economic development. Meanwhile, "The Guiding Opinions on Promoting International Capability and Equipment Manufacturing Cooperation" clearly pointed out that "it is necessary to increase financial support. And policy banks and development financial institutions should play positive roles in the cooperation. It is also necessary to increase the financial support on international capacity and equipment manufacturing cooperation by various means, such as syndicated loans, export credit and project financing." It can be seen that in the process of promoting international capacity cooperation, finance cannot be absent. Since international capacity cooperation is itself a combination of finance and real economy, financial support has become the starting point and 
key policy support for promoting international capacity-production. This is also in line with the principle of financing, which is the core element for the implementation of the Belt and Road Initiative.

As international capacity cooperation refers to the joint operation for the deployment of capacity supply and demand across countries or regions, including both international trade behaviors and international investment behaviors. Therefore, the theory of international capacity cooperation should be traced back to the earliest international trade theory, such as the theory of comparative advantage, natural resource endowment theory, Keynes international trade theory and trade protectionism theory, etc. Moreover, these international trade theories built the theoretical foundation for the idea of international capacity cooperation which is the further development of international trade theory. However, due to the short time for the international capacity cooperation, the corresponding number of research literatures is not much. Xia [8] pointed out that the framework for building international capacity cooperation should formulate corresponding promotion and supporting policies and measures in fiscal and tax, financial and insurance, foreign trade and foreign aid. Zhao and Sang [11] argued that supporting manufacturing industry is an entry point for China to participate in the "Belt and Road" international capacity cooperation. From the perspective of global industrial chain, the transfer of international capacity from home to other countries and regions by increasing foreign investment and international trade will help resolve domestic overcapacity, boost industrial transformation and upgrading, and achieve complementary advantages of countries and optimize resource allocation. In view of the important role of overseas resource development in international capacity cooperation, China should pay more attention to the benign development of the exploitation of overseas resource especially through the exploitation of overseas resources to enter the target market, and build a cross-border industrial chain based on the development of resources to promote international capacity to a higher level [10].The research of Chen et al. [1] pointed out that China should give full play to its own national competitive advantages in the process of participating in international capacity cooperation, focusing on the study of the choices in foreign direct investment, international trade, financial support and global governance, and propose a differentiated coping strategy. With regard to the role of finance in international capacity cooperation under "the Belt and Road Initiative", Tan [6] argued that in order to promote international capacity cooperation, a financial support system should be established to give play to the leading role of development and policy finance, the exploration role of private capital, the financing role of commercial banks and financial markets, and the role of comprehensive financial services. Qiao and Zhang [5] also found that financial support is an important prerequisite for advancing international capacity cooperation. The choice of ways not only needs to consider the realization of national interests, but also must pay great attention to the improvement of welfare in other countries. As the core of the modern economy and the hub of resources and energy, finance has exerted an important influence on international capacity cooperation [9]. What's more, $\mathrm{Wu}$ and Duan [7] believes that the establishment of a three-region model for the trans-regional flow of capital between two countries, has important implications for reshaping "the Belt and Road Initiative" and international capacity cooperation strategy under China's economic geography.

However, unlike the existing literatures, on the one hand, from the point of view of policy financial, this paper divides policy finance into supporting finance, development finance, compensatory finance and welfare finance. Then it discusses the role of financial in international capacity cooperation. On the other hand, this paper focuses on the corresponding research on international capacity cooperation between China and the countries along the "Chongqing-Xinjiang-Europe". 


\section{AN ANALYSIS OF THE SUPPORTING ROLE OF SUPPORTIVE FINANCE IN INTERNATIONAL CAPACITY COOPERATION}

Supporting finance, through the activities of policy financial institutions, fully reflects the policy intention of the government to promote the development of specific components of the economic system. China's supporting finance is centered on China's Export-Import Bank, focusing on achieving the government's overall interest orientation for economic and social development. During the process of international capacity cooperation, it plays an important role, which is guiding, international, professional, and innovative, in the supporting economic activities of Chinese enterprises "going out" and high-tech industrialization with its unique nature and advantages.

Supporting enterprises to "going out" is an important part of international capacity cooperation. Its promotion cannot be separated from policy financial institutions. China established the China Development Bank (CDB) and the Export-Import Bank of China (EIBC) in 1994. In 2001, China Export Credit Insurance Corporation was established. Since they were established, policy development institutions such as the China Development Bank, ExportImport Bank of China and China Export Credit Insurance Corporation have served as practitioners of the country's "going out" strategy. These institutions have supported a series of major projects and effective financing through the provision of credit, insurance and guarantees. Meanwhile, they have effectively promoted the smooth connection of facilities and trade, and have made positive contributions to Chinese enterprises' overseas investment and market development.

First of all, China Development Bank has built a network layout covering most of the world. The development of the $\mathrm{CDB}$ has provided financial services to China's enterprises in infrastructure and pillar industry construction, support for the export of mechanical and electrical products and complete sets of equipment, as well as the implementation of "going out" strategies, etc. It also has made positive contributions to coping with the international financial crisis [2]. Second, the Export-Import Bank of China provided a strong financial guarantee for China's implementation of the "going out" strategy, expanding space for China's economic development, and vigorously supporting and promoting the consolidation and development of traditional export markets through export credit, foreign preferential loans and other businesses. Meanwhile, it has constantly explored emerging markets such as the Middle East, Latin America and Africa. In addition, since the establishment of China Export Credit Insurance Corporation, it has been a professional export credit institution like the EIBC. It has also set up branches or working groups in key business areas of the "Belt and Road" initiative, and has always been committed to providing export credit insurance services for major foreign engineering contracts, export of complete sets of equipment, large-scale electromechanical products and high-tech exports.

Supporting finance, in the process of international capacity cooperation, has also played an important role in accelerating the industrialization of high-tech industries and enhancing national innovation capabilities. In the current environment of deepening reform of the world economic market and optimization and upgrading of industrial structure, the high-tech industry that develops at a high speed is a high-risk behavior. At the same time, it faces technical, market and financial risks. Moreover, it has extremely high growth as well as benefits and the need for high investment. So the high-tech products have strong public and externality. These characteristics make it necessary to support international capacity cooperation, but itself also needs the support of supporting financial institutions to improve the efficiency of resource allocation, and thus build solid financial support for the development 
of high-tech industrialization. As supportive financial institutions, under the guidance of government's fiscal and tax, import and export, foreign exchange, and government procurement policies etc., policy banks will provide high-tech enterprises with credit funds or guarantees, low-interest loans, and financing through participation etc. in their early stages of industrialization and commercialization of scientific and technological achievements. In addition, policy banks will provide tax incentives and subsidies for high-tech industries to encourage further industrialization, and further promote the upgrading of industrial structure, which will become an important way to accelerate the industrialization of high-tech industries.

\section{AN ANALYSIS OF THE SUPPORTING ROLE OF DEVELOPMENT FINANCE IN INTERNATIONAL CAPACITY COOPERATION}

Development finance refers to the statutory financial institution that has specific government empowerment rights. It takes the market-oriented operation mode and market business as the mainstay, actively promotes system construction and market construction through financing to achieve government specific economic and social development goals [4]. As a financial form that combines both government credit and marketization, development finance is centered on the International Development Bank, and can find the best path in the country's will and business needs to make up for "market failure" defects, such as the lack of market credit, institutional imperfections and poor access to the conversion of savings into investment channels, etc.

In November 2013, the Third Plenary Session of the 18th CPC Central Committee promulgated the "Decision of the CPC Central Committee on Several Major Issues Concerning Comprehensively Deepening Reforms", emphasizing "establishing development financial institutions, accelerating the construction of interconnection facilities with neighboring countries and regions, promoting the construction of the Silk Road Economic Belt and the Maritime Silk Road, and creating a new pattern of all-round opening", which shows that development finance has become a pioneer in infrastructure investment projects along the route. Hu [3] pointed out that along the "Belt and Road" are mainly emerging economies and developing countries, so their financial strength is generally weak and infrastructures are imperfect. Meanwhile, faced with the problems of shortage of construction funds, lack of technology and experience, the solution to these problems requires a large amount of funds and a long period of investment return, and the profit margins are narrow so that commercial finance is often unwilling to invest. Therefore, it requires the full play of the role of development finance as well as long-term investment and financing to promote regional economic development.

The China Development Bank, as a development financial institution of the Chinese government, has good experience and capital accumulation in infrastructure construction, and can leverage on the advantages of infrastructure construction, medium and long-term investment and financing and international business. Then through the construction of countries along the "Chongqing-Xinjiang-Europe", a "win-win" situation has emerged. What's more, the four major state-owned commercial banks can utilize their rich experience in international banking operations, industrial funds and midstream and downstream operations for project development, and through the establishment of industrial funds and branch offices, follow-up of major overseas projects, as well as remote service and overseas project marketing working groups, etc., the business will comprehensively cover countries along the "ChongqingXinjiang-Europe".

At the same time, as a representative of policy finance, development finance plays an important role in the construction of international infrastructure along the "Chongqing-Xinjiang-Europe". 
It can also take advantages of its own capital base and influence to provide early support and guarantees for other financial and economic forms to enter the economic environment built by the countries along the "Chongqing-Xinjiang-Europe". Through the positive cooperation with Asian Investment Bank, BRIC Bank and Silk Road Funds, to realize cooperation and resource sharing in terms of project planning and development, investment and financial innovation as well as different industries such as oil and gas, nuclear power, high-speed rail, equipment and ports. And finally to build an important financial platform for international capacity cooperation and help Chinese companies to lay a broader foundation for better international capacity cooperation.

\section{AN ANALYSIS OF THE SUPPORTING ROLE OF COMPENSATORY FINANCE IN INTERNATIONAL CAPACITY COOPERATION}

Compensatory finance refers to compensate for the deficiencies of certain weak industries or financial street economic forms through the activities of policy financial institutions, or give benefit compensation to specific vulnerable groups. It is different from development finance which emphasizes the promotion of overall economic efficiency through policy-based financial measures, while compensatory finance emphasizes more on compensating for the loss of efficiency caused by the unbalanced industrial structure and promoting the development of these disadvantaged industries. Therefore, in this sense, compensatory finance can be used as a powerful complement to national fiscal policies. On the other hand, in the context of international capacity cooperation, it plays an important role in compensating for commercial financial deficiencies and compensating specific groups.

After the "Belt and Road" strategy and international capacity cooperation were put forward, it provided a more diverse and open development path for domestic financial markets. On the international front, commercial financial institutions are actively innovating investment and financing channels during the construction of the "Belt and Road" initiative, which will lead to a new pattern of finance. However, on the one hand, ordinary commercial finance may not be able to enter certain investment areas of international capacity cooperation. On the other hand, there are large demands for funds, long investment terms, large uncertainties in returns, etc. in areas such as infrastructure construction and energy development. Meanwhile, the exchange rate risks and country-specific risks are both large. As a result, the exchange rates of some countries along the route fluctuate drastically. Some enterprises have difficulty in collecting payments, the shrinking of payments causes the deterioration of business operations, and the ability to repay loans declines. Then commercial bank loans will face enormous risks, and financial institutions will not actively enter the market in consideration of the return period of investment. And this will lead to a large investment gaps, which makes commercial financial institutions have great limitations in international capacity cooperation. Therefore, although commercial finance is more efficient, it is not sufficient to meet the needs of some groups and fields in the process of socio-economic development. Moreover, policy finance happens to be an effective supplement to places where commercial finance cannot be reached or reluctant to touch, so that finance can serve the economy better. Through macroeconomic adjustment, compensatory finance uses the participation of the government to conduct specific investment activities and subsidies for certain groups. It also pays more attention to the social rationality of resource allocation in international capacity cooperation and promotes balanced development of the economy. 


\section{AN ANALYSIS OF THE SUPPORTING ROLE OF WELFARE FINANCE IN INTERNATIONAL CAPACITY COOPERATION}

Welfare finance means that the government promotes the general improvement of the residents' living standards through political financial measures, pursues the goal of maximum social benefits, and lays the foundation for achieving common prosperity. Different from the functions of development finance, supportive finance and compensatory finance, welfare finance emphasizes more on the issue of fairness under the conditions of market economy, which means that the government compensates for the loss of social welfare caused by market competition that mainly pursues efficiency through policy financial measures. It can establish special policy financial institutions to provide financial support for the re-employment of certain groups of people, such as unemployed and laid-off workers, veterans, invalids and other vulnerable groups. In addition, it can also encourage their entrepreneurship and use the country's macro-control capabilities and national financial resources to ease the pressure on the basic social security system.

The most important point is to create conditions for the development of domestic economy after putting forward the international capacity cooperation. Therefore, it is also very important to give play to social security, narrowing the gap between the rich and the poor and promoting social equity. Then utilize welfare finance to provide social assistance and financial support for the most vulnerable groups in the society, such as those who have lost their ability to work, suffered natural disasters or other low-income citizens to maintain their basic survival needs. The use of welfare finance in accordance with the law provides certain services and social benefits, guarantees a certain standard of living for all citizens and improves their quality of life, showing that welfare finance pays great attention to fairness, such as the community's parks, fitness facilities and community life for the elders. In addition, the "New Rural Cooperatives" and "New Rural Insurance," which are promoted greatly, fully cover the vast rural areas. Furthermore, the state provides various benefits for soldiers and their families by offering welfare. Through the construction of special system, as well as the improvement of the social security system, social pension system and medical security system, to achieve national happiness, social equality and people's unity, creating a supportive environment for the full realization of international capacity cooperation.

Welfare finance enables the social security system to be independent of enterprises and institutions, adapting the standards of basic social security to the endurance capacity of certain aspects of China's economic development level, realizing the socialization of social security management and services, and improving the supervision and value-added mechanism of social security funds. Meanwhile, welfare finance help to realize the modern management of a fully functional, wide-ranging, standardized and transparent social security system information network, accelerate the construction of social security legal system, and manage social security funds according to law. And then improve the social security system and adhere to the road of sustainable development with the account of fairness and efficiency.

\section{SUGGESTIONS \\ Based on the national conditions, promote the reform and construction of policy financial institutions}

First of all, with reference to domestic laws, regulations as well as international conventions to strengthen the legislative work of policy finance and separately legislate on policy financial institutions. And the legislation is adopted to clarify the legal status of policy financial institutions and their functional role in the economic development at home and abroad, such as China Export-Import Bank, China Export Credit Insurance Corporation. Second, it is of great importance to deepen the reform of policy financial institutions, promote their complementary 
advantages and establish a rational industrial distribution for international capacity cooperation supported by policy financial institutions. Moreover, it is necessary to straighten out the management system such as the authorization management, account management and capital constraint mechanism, and to give play to the role of corporate governance in the "oneto-one" management of policy financial institutions. So that can ensure that the institutions' strategy is in line with the country's strategic intentions. Then fully integrate the actual situation of the institution to achieve a balanced and sustainable development between national strategies and institutions. Meanwhile, it is essential to establish and improve an assessment system that is different from commercial financial institutions, guide policy agencies to implement functional positioning and play a policy-oriented role by strengthening the assessment of policy financial institutions.

In addition, supporting and accelerating the construction of overseas branches of policy financial institutions is also necessary. Compared to the demand for international capacity cooperation construction, there is still a large gap between the number of overseas institutions and personnel, which is not only unfavorable to increase financial support, but also not conducive to loan risk management, although the network layout of overseas institutions currently covers the countries along the "Chongqing-Xinjiang-Europe",

\section{Adhere to innovation and develop diversified financial}

The construction of international capacity cooperation has many infrastructure projects with large capital investment, long construction period and high risks, which needs requires flexible, efficient and diversified financial support. It also requires all types of financial institutions to adapt to local conditions, tailor the project to the specific conditions of each country and design more targeted, flexible and applicable financial products and financing models constantly. Then enrich financing channels and establish diversified financial support channels will provide much better, more efficient and comprehensive financial support for international capacity cooperation.

We will play a leading role of policy financial institutions and provide export credit insurance through the pre-project loans of Export-Import Bank, Development Bank and CITIC Insurance. What's more, the construction of international capacity cooperation needs policy finance to use government funds effectively, and must actively expand the investment side. Then we can effectively dock private capital and "long tail market" to realize the diversified needs of investors and financing parties through innovative approaches such as PPP projects and alternative finance. Indeed, innovate the use of foreign exchange reserves, broaden the funding sources for policy-based financial institutions and appropriately increase the scale of overseas financing for policy-based financial institutions are also necessary. Furthermore, commercial financial institutions can optimize the product structure by providing various forms of financial services, such as equity financing, pledge loans, import and export trade credits and financial leasing, and then strengthen overseas capital and capacity cooperation in the process of supporting domestic high-quality enterprises to going out.

\section{Pay attention to practice and establish a comprehensive risk management system}

The development of international capacity cooperation means a large number of import and export trades and foreign investment at the economic level. However, on the one hand, many of the countries along the "Chongqing-Xinjiang-Europe" are not China's traditional and mainstream trading partners and investment markets. On the other hand, Chinese companies have low awareness of these countries and their ability and risks may be underestimated. Therefore, on the basis of exploration and practice, combined with the country's new situation 
and requirements of foreign economic and trade, we must establish a comprehensive risk management system that is in line with the national strategy and adaptable to the organization's own capacity, and do a great job in the risk management and prevention during the construction of international capacity cooperation projects.

First of all, we will strengthen investigations into the economic and political system, the investment and institutional environment of the countries along the "Chongqing-XinjiangEurope" to improve the systematic and forward-looking of these researches. Secondly, based on political, economic and trade risks, commercial and investment environmental risks, legal risks and overall risk assessment, they will be given a national risk reference rating to earnestly carry out market research, feasibility studies and performance assessment of specific risks such as financial, completion, legal, exchange rate risk, as well as environmental and social responsibility risk for the projects of enterprises to "going out". Thirdly, we should conduct a comprehensive assessment of trade, investment and capacity cooperation along the "Chongqing-Xinjiang-Europe" countries from a commercial perspective, and then build a risk management system that includes risk appetite, specific risk tolerance indicators, various types of specific business risk management systems and regional financial risk response mechanisms. Moreover, in the process of development, policy financial institutions should establish a long-term capital constraint mechanism to achieve a balance among the implementation of national strategies, low profitability policy businesses and sustainable development of institutions. Then in combination with the external strategy of international capacity cooperation, a unified country quota system should be established to optimize the technology and level of specific risks such as credit risk, insurance risk, market risk and operational risk. At last, promote the internationalization of the rmb can help to facilitate the trade and investment facilitation of countries along the "Chongqing-Xinjiang-Europe". It also can effectively avoid the loss of exchange rate between China and those countries, enhance the ability to withstand financial risks, reduce capital and transaction costs and increase the international competitiveness of the region's economic, financial institutions and enterprises.

\section{Improve macro control and the plan of international capacity cooperation}

Since the introduction of international capacity cooperation, China and the countries along the "Chongqing-Xinjiang-Europe" wait getting with each other in the financial cooperation. China's policy financial institutions and commercial financial institutions are all fighting against each other and have not yet formed a sound business cooperation mechanism. Therefore, we need to implement macro-control through policy finance to further improve the planning of international capacity cooperation.

Improve the planning at the national level, innovate the institutional mechanisms, establish scientific, standardized and effective decision-making mechanisms will help to jointly build enterprise service platforms and integrate financial cooperation into the cooperation track in the economic, political and cultural fields. Then combine with the actual situation among the regions to formulate long-term strategic goals that are in line with the interests of both parties, and take practical and feasible steps to gradually implement the jointly formulated strategic plan. What's more, it needs to strengthen top-level design, establish inter-governmental or inter-regional government cooperation mechanisms along the "Chongqing-Xinjiang-Europe" countries in accordance with regional, industry and industrial development priorities, and take the lead in organizing operations from the top level to promote the strengthening of financial cooperation along the "Chongqing-Xinjiang-Europe" countries. Furthermore, actively connect related projects, integrate and allocate multiple resources, deepen exchanges and cooperation with international multilateral financial institutions such as the World Bank and the Asian Development Bank also helps to keep abreast of the latest policy developments in international 
capacity cooperation and coordinate regional planning and country planning.

\section{ACKNOWLEDGMENT}

The authors acknowledge funding from the key project Chongqing Social Science Foundation of China (Project No. 2016YBJJ029). Besides, Jingjing Luo is the corresponding author and can be contacted at: 631077294@qq.com.

\section{References}

Chen, J.Y., Jiang, Y.P., Wang, B.S.. The "Belt and Road" Initiative Strategy and China's Participation in International Capacity Cooperation [J]. Learning and Practice, 2017(1):5-12.

Chen, Y. Give Play to the Role of Development Finance and Promote China's Economic and Social Sustainable Development [J]. Management World, 2004(7):1-5.

Hu, H.B. Give Play to the Role of Development Finance and Serve the "Belt and Road" Initiative Strategy [J]. Globalization, 2015(5): 20-30.

Li, Z.H., Wang, Y.W.. Research on Developmental Financial Theory - Complementing the Development Finance of Policy Finance [J]. Nankai Economic Studies, 2008(4):3-15.

Qiao, X.N., Zhang, X.N.. Economic Logic of International Capacity Cooperation, Financial Support and Win-win [J]. Industrial Economic Review, 2017(2):39-54.

Tan, L. Build a Financial Support System for International Capacity Cooperation [J]. China Economic and Trade Guide, 2016(16): 62-63.

Wu, F.X., Duan, Y. International Capacity Cooperation and Reshape China's Economic Geography [J]. Chinese Social Sciences, 2017(2):44-64.

Xia, X.L.. Build the "Belt and Road" Initiative International Capacity Cooperation System Mechanism and Policy System [J]. International Trade, 2015(11): 26-33.

You, H.B., Wu, L. Financial Support in International Capacity Cooperation Between China and Foreign Countries [J]. Zhejiang Finance, 2017(4):16-22.

Zhang, S.C.. Research on Transformation and Upgrade of Overseas Resource Development and International Capacity Cooperation: Based on Global Industry Chain Perspective [J]. Shandong Social Sciences, 2016(7):135141.

Zhao, D.L., Sang B.C.. International Capacity Cooperation under the Belt and Road Initiative: An Empirical Analysis Based on the International Competitiveness of Industries [J]. International Trade Issues, 2016(10): 3-14. 